\title{
Effect of exogenous melatonin and exposure to a ram on the time of onset and duration of the breeding season in Icelandic sheep
}

\author{
J. Eldon \\ Institute for Experimental Pathology, University of Iceland, Keldur, IS-112 Reykjavik, Iceland
}

\begin{abstract}
Icelandic ewes, living under natural photoperiod conditions, were treated with daily melatonin ( 2.5 and $10 \mathrm{mg}$ day $\left.^{-1}\right)$ for 75 days from the autumn equinox. Ewes were also exposed to a ram from the autumn equinox until the end of June, for 30 days from the end of the anoestrous period ( 30 October), and from 11 December for 30 days during the oestrous season. Blood samples were collected three times per week from September until the cessation of seasonal ovarian activity and assayed for progesterone. Melatonin treatment did not significantly alter the time of onset or the duration of the breeding season compared with control ewes. There were no significant changes in luteal activity due to melatonin. Ewes exposed to a ram from the autumn equinox had a longer breeding period than did control ewes owing to earlier onset of ovarian activity. Exposure to a ram had a significant effect on luteal activity during the first seasonal ovarian cycle. It is suggested that insignificant response to melatonin treatments and slow response to ram exposure in Icelandic sheep were caused by entrainment of the reproductive endocrine system by the large seasonal changes in the photoperiod.
\end{abstract}

\section{Introduction}

Icelandic sheep, which experience large seasonal changes in photoperiod, are highly seasonal animals that breed during the period of shortest daylength. There is a $17 \mathrm{~h}$ difference in daylength (sunrise-sunset) between the summer and winter solstice. During summer, Icelandic sheep graze on mountain pasture during a photoperiod of almost $24 \mathrm{~h}$ light. During the long dark winters the sheep are housed in barns. Circadian changes in photoperiod are reflected in circadian changes in circulating melatonin from pinealocytes in the pineal gland, and high concentrations during the scotophase (Reiter, 1986, 1989). Malpaux et al. (1988), for example, found high concentrations of melatonin in ewes during 8,12 and $16 \mathrm{~h}$ of darkness under laboratory conditions. A neurochemical pathway including the retina, the suprachiasmatic nucleus and the pineal gland regulates the circadian rhythms that synchronize to alterations in photoperiod (Mess and Rúzsák, 1986; Steinlechner, 1989; Touitou, 1989; Krause and Dubocovich, 1990). The duration of the nocturnal rise in melatonin in the pineal gland owing to photoperiod and the sensitivity of the target organs are probably key factors in initiating the endocrine changes that lead to breeding activity in seasonal breeders (Reiter, 1986, 1987; Illnerová and Humlová, 1990). Sheep and various other mammalian species react to exogenous melatonin with changes in their normal reproductive pattern (Lincoln, 1983; English et al., 1986; Asher et al., 1988; Adam et al., 1989; Nowak et al., 1990). Daily exogenous melatonin, whether given in feed or s.c. during the photophase, increases circulating melatonin and does not seem to shorten the period of endogenous secretion during the scotophase (Robinson et al., 1991, 1992).

Received 1 June 1992.
Another factor that may influence the pattern of ovarian activity of sheep is the introduction of a ram in or out of the breeding season (Edgar and Bilkey, 1963; Grubb and Jewell, 1973; Poindron et al., 1980; Knight, 1983; Martin et al., 1986; Pearce and Oldham, 1988).

The aim of this study was to examine the effects of exogenous melatonin and of exposure to rams on the time of onset and duration of the breeding season, with reference to the changes in photoperiod ( $17 \mathrm{~h}$ difference in daylength between June and December) to which Icelandic sheep are exposed.

\section{Materials and Methods}

\section{Location}

The study took place at the Institute for Experimental Pathology at Keldur, Reykjavík $\left(64^{\circ} 10^{\prime} \mathrm{N}\right)$ where daylength from sunrise to sunset during summer solstice is about $21 \mathrm{~h}$, whereas in December at winter solstice it is about $4 \mathrm{~h}$.

\section{Animals}

Icelandic sheep belong to the North European short-tailed group of sheep and are closely related to the Norwegian Spalsau sheep (Aðalsteinsson, 1981). Adult ewes weigh about $45 \mathrm{~kg}$ and rams about $65 \mathrm{~kg}$. The breeding season is from November to March (Eldon, unpublished). The ewes mate in December and have 1-2 lambs in May. Icelandic ewes and rams, 3-5 years of age, were housed in bright, unheated and well-ventilated barns under natural seasonal variations of daylight (no artificial light). The sheep were fed abundant hay twice a day and fresh water and mineral stone were always available. 


\section{Melatonin treatments}

Four ewes were fed melatonin, $2.5 \mathrm{mg} \mathrm{day}^{-1}$, for 75 days from the autumn equinox or 22 September to 6 December. The melatonin was dissolved in $96 \%$ ethanol and adsorbed on rye bread. Four ewes were injected daily s.c. with $2.5 \mathrm{mg}$ of melatonin in $1 \mathrm{ml}$ of sterile saline for the same period. Four control ewes were fed rye bread and four were injected daily with saline. The melatonin was administered $4 \mathrm{~h}$ before sunset to simulate a $4 \mathrm{~h}$ shorter daylength than was prevailing. The experiment was repeated in the following year with $10 \mathrm{mg}$ melatonin day ${ }^{-1}$. The dose of $2.5 \mathrm{mg}$ melatonin day ${ }^{-1}$ was chosen in the light of effects reported by, for example, Lincoln (1983), English et al. (1986), Tekpetey and Amann (1988) and Robinson et al. (1991). The time period and time of year were chosen with reference to the change in the natural light:dark cycle occurring at the autumn equinox when the days start to get shorter than the night and in relation to the time of the breeding season which starts in November. The dose of $10 \mathrm{mg}$ melatonin day ${ }^{-1}$ was chosen to determine whether a higher dose had a more pronounced effect.

\section{Exposure to a ram}

Eight ewes were housed with a vasectomized ram in the same pen from the autumn equinox, 22 September until 1 July, to study the effect of a ram on the onset of seasonal ovarian activity. Four ewes were housed in a separate pen where they could see, hear and smell the ram but tactile contact was not possible. Six control ewes were housed in a separate barn. The ram showed sexual behaviour towards the ewes immediately after introduction. The experiment was repeated the following year. To study how readily ewes responded to a ram at the beginning of the reproductive season, five anoestrous ewes were introduced to a vasectomized ram on 30 October, at the end of the anoestrous period and stayed with the ram for 30 days. Five oestrous ewes were introduced to a ram on 11 December to determine whether ovarian cyclicity became synchronized within a group of cyclic ewes at the introduction of a ram. These ewes stayed with the ram for 30 days. The time of year of exposure to the rams was chosen, as with melatonin, in relation to the change in the natural light:dark cycle occurring at the autumn equinox, the time of onset and duration of the breeding season.

\section{Collection of blood samples and assays}

Four millilitres of blood were collected for progesterone assay from the jugular vein three times a week from the beginning of September until the cessation of seasonal ovarian activity. Plasma was harvested within $1 \mathrm{~h}$ from sampling and stored at $-20^{\circ} \mathrm{C}$ until assayed.

Progesterone was assayed in plasma using Coat-A-Count solid phase radioimmunoassay kit from Diagnostic Products Corporation (DPC; Los Angeles, CA). Inter- and intra-assay coefficients of variation were $9.3 \%$ and $7.5 \%$, respectively, for a true-value control sample containing $4.8 \pm 0.7 \mathrm{nmol}^{-1}$. The mean of 50 assays of this control sample in 50 different assays was $4.77 \pm 0.4 \mathrm{nmol} \mathrm{l}^{-1}$.

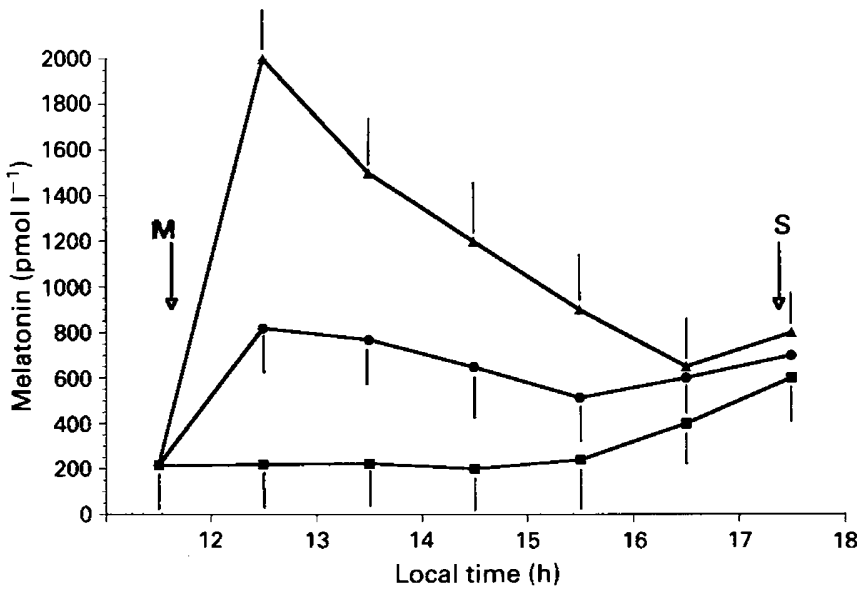

Fig. 1. Serum concentration of melatonin (mean \pm SD) after adminis-

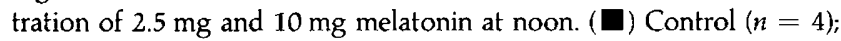
(O) $2.5 \mathrm{mg}$ melatonin ( $n=8 ; 4$ per os; 4 s.c.); ( $\Delta$ ) $10 \mathrm{mg}$ melatonin ( $n=8 ; 4$ per os; 4 s.c.). M: time of melatonin administration; S: sunset.

Blood was collected every hour for $6 \mathrm{~h}$ from 16 ewes given melatonin at noon on 5 November to determine the rise of melatonin after administration. Melatonin was given as described above to four groups of four ewes and four ewes were controls. Melatonin was assayed using ${ }^{125}$ I radioimmunoassay kit from Elias (Osceola, WI). Inter- and intra-assay coefficients of variation were $11 \%$ and $15 \%$, respectively, for an Elias control sample containing $108 \mathrm{pmol}^{-1}$. Samples with high concentration were diluted with melatonin-free sheep serum.

\section{Statistical analysis}

The date of onset of ovarian cyclicity was the sample date before progesterone rose above $3 \mathrm{nmol} \mathrm{l}^{-1}$ in two successive serum samples (English et al., 1986). The duration of the luteal phase was evaluated from the day progesterone rose above $3 \mathrm{nmol}^{-1}$ to the day before it fell below the same value. The area under the progesterone curve was calculated using the formula $\int a x+b d x$ (Machin, 1976). For a numerical evaluation, the number of days from the autumn equinox to the onset and cessation of the seasonal ovarian activity was used. A statistically valid control group was obtained by combining the data from all control groups as the statistical difference between the groups was not significant $(P>0.05)$. The data were evaluated by analysis of variance and Student's $t$ test (Sokal and Rohlf, 1981) using the StatView $512+$ (Brain Power, Inc., Calabasas, CA) software for Macintosh computers.

\section{Results}

\section{Effect of melatonin}

Administration of $2.5 \mathrm{mg}$ melatonin gave a significant rise for $5 \mathrm{~h}$ compared with controls and $10 \mathrm{mg}$ melatonin gave a significant rise for the $6 \mathrm{~h}$ that melatonin was monitored (Fig. 1). No difference was seen between ways of administration (per os versus s.c.). Melatonin did not alter the onset or duration of the 
Table 1. The dates of the onset of breeding season of control ewes, ewes that were given melatonin and ewes that were housed with a ram

\begin{tabular}{lccc}
\hline Variable & Control & Melatonin & Ram \\
\hline $\begin{array}{l}\text { Number of ewes } \\
\begin{array}{l}\text { Mean date of onset } \\
\text { of breeding season }\end{array}\end{array}$ & 20 & 16 & 16 \\
SD & 8 & 7 Nov & 3 Nov $^{*}$ \\
$50 \%$ & 11 Nov & 10 & 10 \\
$75 \%$ & 19 Nov & 10 Nov & 31 Oct \\
$90 \%$ & 24 Nov & 18 Nov & 12 Nov \\
Range & 24 days & 33 days & 29 days \\
\hline
\end{tabular}

${ }^{*}$ Significantly different from control values $(P<0.05)$.

Table 2. The dates of the cessation of the breeding season in control ewes, ewes that were given melatonin and ewes that were housed with a ram

\begin{tabular}{llcc}
\hline Variable & Control & Melatonin & Ram \\
\hline $\begin{array}{l}\text { Number of ewes } \\
\begin{array}{l}\text { Mean date of cessation } \\
\quad \text { of breeding season }\end{array}\end{array}$ & $20 \mathrm{Feb}$ & $12 \mathrm{Feb}$ & $8 \mathrm{Mar}$ \\
$\mathrm{SD}$ & 30 & 24 & 39 \\
$50 \%$ & $13 \mathrm{Feb}$ & $6 \mathrm{Feb}$ & $13 \mathrm{Feb}$ \\
$75 \%$ & $3 \mathrm{Mar}$ & $26 \mathrm{Feb}$ & $5 \mathrm{Apr}$ \\
$90 \%$ & $28 \mathrm{Mar}$ & $16 \mathrm{Mar}$ & $13 \mathrm{May}$ \\
Range & 93 days & 75 days & 118 days \\
\hline
\end{tabular}

Table 3. The duration of the breeding season in control ewes, ewes that were given melatonin and ewes that were housed with a ram

\begin{tabular}{lccc}
\hline Variable & Control & Melatonin & Ram \\
\hline $\begin{array}{l}\text { Number of ewes } \\
\begin{array}{l}\text { Mean duration of } \\
\text { breeding season (days) }\end{array}\end{array}$ & 20 & 16 & 16 \\
SD & 26 & 96 & $122^{*}$ \\
\hline
\end{tabular}

${ }^{*}$ Significantly different from control value $(P<0.05)$

breeding season (Tables $1-3$ ). There was no difference in time of onset or duration of seasonal ovarian cyclicity between melatonin treatments (per os versus s.c.; $2.5 \mathrm{mg}$ day $^{-1}$ versus $10.0 \mathrm{mg} \mathrm{day}^{-1}$, respectively; $P>0.05$ ). The duration of the luteal phase and the area under the luteal phase progesterone curve of the first three ovarian cycles of the breeding season in ewes treated with melatonin were similar to those in control ewes.

\section{Effect of a ram}

Seasonal ovarian activity in ewes that were housed with rams from the autumn equinox started significantly earlier (10 \pm 6 days; $P<0.05)$ than in control ewes (Table 1$)$. The first ewes started ovarian cyclicity 29 days after introduction of a ram. The average was $42 \pm 10$ days from autumn equinox or 3 November. The seasonal ovarian activity did not stop significantly later $(P>0.05$; Table 2$)$, but the duration of the breeding season was significantly greater than in control ewes $(P<0.05$; Table 3).

The ewes introduced to a ram at the end of the anoestrous period, 30 October, showed onset of ovarian activity 2-20 days after exposure. The average was $11 \pm 8$ days after introduction on 10 November. This was not significantly different from control ewes. The cessation and duration of the breeding season in these ewes was the same as in control ewes.

The ewes that were in visual, auditory and olfactory contact with a ram had the same time of onset and cessation of ovarian activity as the ewes that were in the pen with a ram. The number of days from when the first ewe started seasonal ovarian activity to the last or the rate of onset of ovarian activity was similar in ewes housed with a ram to that in control ewes but the rate of cessation was slower (Tables 1 and 2).

The ovarian cyclicity was not synchronized within the group of five ewes introduced to rams on 11 December. One ewe had a disrupted luteal phase and a 7 day ovarian cycle. Thereafter as previously this ewe cycled normally. No synchronization of ovarian cyclicity was found in the other groups.

The duration and the amplitude of progesterone response of the luteal phases during the first three ovarian cycles of the breeding season in ewes housed with the rams was not significantly different from those in the control ewes $(P>0.05)$. The area under the progesterone curve during the luteal phase of the first ovarian cycle of the breeding season in ewes housed with a ram from the autumn equinox was significantly larger than that in control ewes (Table $4 ; P<0.01$ ).

\section{Discussion}

Daily administration of melatonin for 75 days from the autumn equinox, timed to simulate $4 \mathrm{~h}$ shorter than prevailing daylength, failed to advance the onset of seasonal ovarian activity significantly. English et al. (1986), Waller et al. (1988) and Nowak et al. (1990) reported that oestrus could be advanced by melatonin feeding as well as by implants. These authors started the melatonin feeding in April-July, whereas in the present study melatonin feeding was started at the autumn equinox on 22 September. Melatonin feeding that started just after the summer solstice may be more effective in shifting forward the onset of the breeding season. Another reason for the poor response in Icelandic sheep could be the differences in seasonal photoperiod, probably through entrainment of endogenous changes in reproductive activity (Ebling and Foster, 1988). Entrainment is the synchronization or setting of certain physiological activities by repeating factors such as photoperiod: for example the daily physiological effect of the light:dark cycle on the retina-hypothalamus-pineal axis, which in turn has its effects on the hypothalamus-hypophyseal-gonadal axis and 
Table 4. The amplitude of progesterone and the area under the progesterone curves during the 1,2 and 3 luteal phases of the breeding season

\begin{tabular}{|c|c|c|c|c|c|c|c|c|c|}
\hline \multirow{2}{*}{$\begin{array}{l}\text { Progesterone } \\
\text { response }\end{array}$} & \multicolumn{3}{|c|}{ Control } & \multicolumn{3}{|c|}{ Melatonin } & \multicolumn{3}{|c|}{ Ram } \\
\hline & 1 & 2 & 3 & $I$ & 2 & 3 & 1 & 2 & 3 \\
\hline $\begin{array}{l}\text { Number of ewes (number of luteal } \\
\text { phase samples) }\end{array}$ & 20 & $\begin{array}{l}20 \\
(100)\end{array}$ & 20 & 16 & $\begin{array}{l}16 \\
(80)\end{array}$ & 16 & 16 & $\begin{array}{l}16 \\
(80)\end{array}$ & 16 \\
\hline $\begin{array}{l}\text { Mean amplitude of progesterone } \\
\text { response }\left(\mathrm{nmol} \mathrm{l}^{-1}\right)\end{array}$ & 7.0 & 8.6 & 7.7 & 6.5 & 7.3 & 6.9 & 8.2 & 9.0 & 9.2 \\
\hline SD & 1.5 & 1.6 & 1.5 & 1.7 & 2.0 & 1.7 & 1.7 & 1.8 & 1.8 \\
\hline $\begin{array}{l}\text { Mean area under progesterone } \\
\text { curve (arbitrary units) }\end{array}$ & 70 & 90 & 98 & 69 & 83 & 96 & $92^{*}$ & 103 & 107 \\
\hline SD & 19 & 28 & 30 & 27 & 30 & 25 & 22 & 22 & 20 \\
\hline
\end{tabular}

*Significantly different from control values $(P<0.05)$

thus stimulates or inhibits seasonal sexual activity (Illnerová and Vanecek, 1986; Lerchl and Küderling, 1989; Arendt 1992; Haus and Touitou, 1992). Ewes exposed to large changes in seasonal photoperiod could be less susceptible to effects of exogenous melatonin, owing to entrainment, than ewes exposed to small changes. Another plausible explanation is that at the autumn equinox the ewes had already received their inductive photoperiodic signal with decreasing daylength from the summer solstice (Robinson and Karsch, 1984). In this case a $5 \mathrm{~h}$ decrease in daylength suffices to set the time for the oncoming breeding season in Icelandic sheep.

The exogenous melatonin did not significantly change the time of cessation or the duration of the breeding season. This result is in accord with the findings of Johnston et al. (1988) and Jordan et al. (1990) and emphasizes the entrainment theory.

The $10 \mathrm{mg}$ melatonin day ${ }^{-1}$ dose gave similar results to the $2.5 \mathrm{mg}$ melatonin day ${ }^{-1}$, but slightly delayed the cessation of ovarian activity. It is possible that even higher doses would have significant effects. The method of melatonin administration, per os and s.c., gave similar concentrations of melatonin in blood and similar results in time of onset, cessation and duration of the breeding season. Melatonin given s.c. is absorbed into the bloodstream and thus enters the systemic circulation, whereas the melatonin given per os passes from the intestines to the liver by the portal blood before entering the systemic circulation. Melatonin is metabolized to 6-hydroxymelatonin in the liver (Kopin et al., 1961; Berthelot et al., 1990; Krause and Dubocovich, 1990). A difference in effect between routes of administration would therefore be expected.

Exposure to a ram advanced the time of onset of seasonal ovarian cyclicity by $10 \pm 6$ days; the first ewes ovulated 29 days after exposure. It has been reported that the response to a ram exposure differs among breeds and even among flocks of the same breed (Underwood et al., 1944; Martin, 1984; Martin et al., 1986; Pearce and Oldham, 1988). Some breeds, for example the Merino, are reported to respond immediately to exposure to a ram and to ovulate within 1-2 days; other breeds, for example Romney Marsh and Border Leicester $\times$ Scottish Blackface, respond only towards the end of the anovulatory period (Poindron et al., 1980; Martin, 1984). At the time of exposure to a ram during the autumn equinox the ewes were clearly in 'deep anoestrus' which accounts for their failure to respond. However, the ewes exposed to a ram at the end of the anoestrous period ( 30 October) also reacted slowly as only one ewe ovulated within 2 days of exposure to a ram and the others 10-20 days later. Entrainment due to photoperiod changes and the need for a long period for the resensitization to short days are plausible explanations (Khalid and Jackson, 1991).

In contrast to the findings of Grubb and Jewell (1973) and Martin (1984) the ram did not establish synchrony in ovarian cyclicity in the ewes. Only one oestrous ewe had disrupted luteal activity when exposed to a ram. Exposure to a ram did not affect the duration of the luteal phase of the ovarian cycle, but its effect on the activity of the corpus luteum was significant as shown by a larger area under the luteal phase progesterone curve, later cessation of seasonal ovarian activity and a longer breeding season than was seen in control ewes. Wayne et al. (1989) showed that long-term exposure to other sheep can synchronize the start of the breeding season in pinealectomized ewes that otherwise would have shown desynchronized reproductive activity. There is also a more acute response to rams. That is, introduction of a strange ram to a flock of ewes at the end of the anoestrous season can synchronize oestrus at the start of the breeding season. Although the ewes in the present study were introduced to a strange ram at the end of anoestrus, they did not show the acute effects on synchronization of oestrus; neither did the ewes exposed to a ram from the autumn equinox to 1 July.

The ewes had not previously been exposed to a ram. Perhaps this lack of experience impeded oestrus sychronization.

The time of onset of seasonal ovarian activity was the same in ewes with indirect and direct contact with a ram. This finding is in accord with the findings of Watson and Radford (1960) for Merino ewes and suggests that the ram stimuli is visual, olfactory, auditory or tactile.

A significantly longer reproductive period ( 28 days) in ewes exposed to rams than in control ewes was caused by earlier onset of ovarian activity. Continuous exposure to a ram did not maintain the breeding season, and this is in accord with Martin (1984). The inhibitory effect of increasing photoperiod on the neuroendocrine system is clearly stronger than the stimulation from the ram.

In conclusion, melatonin treatment for 75 days had no significant effect on the onset or duration of the breeding season of 
the ewes. The ewes did not react immediately to exposure to a ram, either during the anoestrous period or at the end of that period. However, the ram effect was clearly established and could be seen in increased luteal activity and longer reproductive season than was seen in control ewes. The Icelandic sheep came from Norway with the first settlers in the ninth and tenth centuries. (A Jalsteinsson, 1981) and since then very few sheep have been imported. The animals are housed during 7-8 months of winter, but are grazed on mountain ranges during summer. The Icelandic sheep is thus an isolated, genetically pure highly domesticated breed living under great seasonal change in photoperiod. A probable cause for the lack of response to melatonin and slow response to a ram is entrainment of the reproductive endocrine system by the large seasonal changes in photoperiod that the ewes had experienced before and during the experiment and to which this race of sheep has been exposed through the centuries.

The author thanks E. Gunnarsson for his expert surgical help and $\mathrm{G}$. Agnarsdóttir and $\mathrm{H}$. Briem for reading the manuscript and correcting the English. This study was supported by the Icelandic Science Fund.

\section{References}

Afalsteinsson S (1981) Origin and conservation of farm animal populations in Iceland Sonderdruck aus Zeitschrift für Tierzüsuchtung und Züchtungsbiologie 98 258-264

Adam CL, Moir CE and Shiach P (1989) Melatonin can induce year-round ovarjan cyclicity in red deer (Cervus elaphus) Joumal of Reproduction and Fertility $\mathbf{8 7}$ 401-408

Arendt J (1992) The pineal. In Biologic Rhythms in Clinical and Laboratory Medicine pp 348-362 Eds $Y$ Touitou and E Haus. Springer-Verlag, Berlin

Asher GW, Barrell GK, Adam JL and Staples LD (1988) Effects of subcutaneous melatonin implants on reproductive seasonality of farmed fallow deer (Dama dama) Joumal of Reproduction and Fertility 84 679-691

Berthelot X, Laurentie M, Ravault JP, Ferney J and Toutain PL (1990) Circadian profile and production rate of melatonin in the cow Domestic Animal Endocrinology $7315-322$

Ebling FJP and Foster DL (1988) Photoperiod requirements for puberty differ from those for the onset of the adult breeding season in female sheep Journal of Reproduction and Fertility 84 283-293

Edgar DG and Bilkey DA (1963) The influence of rams on the onset of the breeding season in ewes Proceedings of the New Zealand Sociefy of Animal Production 23 79-87

English J, Poulton AL, Arendt J and Symons AM (1986) A comparison of the efficiency of melatonin treatments in advancing oestrus in ewes Journal of Reproduction and Fertility $77321-327$

Grubb P and Jewell PA (1973) The rut and the occurrence of oestrus in the Soay sheep on St Kilda Journal of Reproduction and Fertility Supplement 19 491-502

Haus E and Touitou Y (1992) Principles of clinical chronobiology. In Biologic Rhythms in Clinical and Laboratory Medicine pp 6-34 Eds $Y$ Touitou and E Haus. Springer-Verlag, Berlin

Illnerová $H$ and Humlová M (1990) Melatonin entrains a circadian rhythm of its own production. In Advances in Pineal Research Vol. 4 pp 59-64 Eds RJ Reiter and A Lukaszyk. John Libbey, London

Ilnerová $\mathrm{H}$ and Vanecek J (1986) Effect of light on the $\mathrm{N}$-acetyltransferase rhythm in the rat pineal gland. In Advances in Pineal Research Vol. 1 pp 69-76 Eds RJ Reiter and M Karasek

Johnston JPJ, Quirke JF, Boland MP and Roche JF (1988) The effect of continuous or intermittent melatonin on seasonal breeding of ewes. 11th International Congress on Animal Reproduction and Artificial Insemination, Dublin 4408

Jordan B, Hanrahan JP and Roche JF (1990) The effect of melatonin implantation in the middle of the breeding season on the subsequent reproductive activity of Scottish Blackface ewes Animal Reproduction Science 23 41-48
Khalid M and Jackson GL (1991) Exposure of ewes to long-day photoperiods before the winter solstice can disrupt refractoriness to short days Animal Reproduction Science 25 225-232

Knight TW (1983) Ram-induced stimulation of ovarian and oestrous activity in anoestrous ewes - a review Proceedings of the New Zealand Society of Animal Production 43 7-11

Kopin IJ, Pare CMB, Axelrod J and Weissbach H (196I) The fate of melatonin in aniamls Journal of Biological Chemistry 236 3072-3075

Krause D and Dubocovich ML (1990) Regulatory sites in the melatonin system of mammals Trends in Neurosciences 13 464-470

Lerchl A and Küderling I (1989) Gonadal steroid excretion and daily locomotor activity patterns in saddle back tamarins (Saguinus fuscicollis; Callitrichidae; primates): influence of melatonin and light/dark cycles. In Advances in Pineal Research Vol. 3 pp 271-276 Eds RJ Reiter and SF Pang. John Libbey, London

Lincoln G (1983) Melatonin as a seasonal time-cue: a commercial story Nature 302755

Machin D (1976) Biomathematics: an introduction pp 151. The Gresham Press, Old Woking

Malpaux B, Robinson JE, Brown MB and Karsch FJ (1988) Importance of changing photoperiod and melatonin secretory pattern in determining the length of the breeding season in the Suffolk ewe Joumal of Reproduction and Fertility $83461-470$

Martin GB (1984) Factors affecting the secretion of luteinizing hormone in the ewe Biological Review 59 1-87

Martin GB, Oldham CM, Cognie Y and Pearce D (1986) The physiological response of anovulatory ewes to the introduction of rams - a review Livestock Production Science 15 219-247

Mess B and Rúzsák C (1986) Relationship between suprachiasmatic nuclei and rhythmic activity of the pineal gland. In Advances in Pineal Research Vol. I PP 149-158 Eds RJ Reiter and M Karasek. John Libbey, London

Nowak R, Rajkumar RR, Webley GE and Rodway RG (1990) Effect of prolonged exposure to exogenous melatonin on the onset and end of the breeding season and on the growth rate of ewe lambs British Veterinary Journal 146 $17-23$

Pearce GP and Oldham CM (1988) Importance of non-olfactory ram stimuli in mediating ram-induced ovulation in the ewe Journal of Reproduction and Fertility $84333-339$

Poindron P, Cognie Y, Gayerie F, Orgeur P, Oldham CM and Ravault J-P (1980) Changes in gonadotrophin and prolactin levels in isolated seasonally or lactationally anovular ewes associated with ovulation caused by the introduction of ram Physiology and Behaviour 25 227-236

Reiter RJ (1986) Pineal melatonin production: photoperiodic and hormonal influences. In Advances in Pineal Research Vol. I pp 77-87 Eds RJ Reiter and M Karasek. John Libbey, London

Reiter RJ (1987) Mechanisms of control of reproductive physiology by the pineal gland and its hormones. In Advances in Pineal Research Vol. 2 pp 109-125 Eds RJ Reiter and F Fraschini. John Libbey, London

Reiter RJ (1989) Melatonin: its sources, its message, and the interpretation of the message. In Advances in Pineal Research Vol. 3 pp 165-173 Eds RJ Reiter and SF Pang. John Libbey, London

Robinson JE and Karsch FJ (1984) Refractoriness to inductive day lengths terminates the breeding season of the Suffolk ewe Biology of Reproduction 31 656-663

Robinson J\}, Wigzell S, Aitken RP, Wallance JM, Ireland S and Robertson IS (1991) The modifying effects of melatonin, ram exposure and plane of nutrition on the onset of ovarian activity, ovulation rate and the endocrine status of ewes Animal Reproduction Science 26 73-91

Robinson JJ, Wigzell S, Aitken RP, Wallance JM, Ireland S and Robertson IS (1992) Daily oral administration of melatonin from March onwards advances by 4 months the breeding season of ewes maintained under the ambient photoperiod at $57^{\circ} \mathrm{N}$ Animal Reproduction Science 27 141-160

Sokal RR and Rohlf FJ (1981) Biometry 2nd edn pp 859. WH Freeman and Company, New York

Steinlechner S (1989) Is there a feedback loop between the pineal gland and the retina? In Advances in Pineal Research Vol. 3 pp 175-180 Eds RJ Reiter and SF Pang. John Libbey, London

Tekpetey FR and Amann RP (1988) Effects of exogenous melatonin prior to the breeding season on testis weight and epididymal androgen receptors in rams Domestic Animal Endocrinology 5 257-264

Touitou Y (1989) Pineal and hypothalamo-pituitary-adrenal axis: in search for interaction. In Advances in Pineal Research Vol. 3 pp 241-246 Eds RJ Reiter and SF Pang. John Libbey, London 
Underwood EJ, Shier FL and Davenport N (1944) Studies in sheep husbandry in W.A. V. The breeding season in Merino, crossbred and British Breed ewes in the agricultural districts Journal of Agriculture (Western Australia) II 135-143 Waller SL, Hudgens RE, Diekman MA and Moss GE (1988) Effect of melatonin on induction of estrous cycles in anestrous ewes Joumal of Animal Science 66 $459-463$
Watson RH and Radford HM (1960) The influence of rams on onset of oestrus in Merino ewes in the spring Australian Journal of Agricultural Research II 65-71

Wayne NL, Malpaux B and Karsch FJ (1989) Social cues can play a role in timing onset of the breeding season of the ewe Jourmal of Reproduction and Fertility $\mathbf{8 7}$ 707-713 